\title{
Assessing Exposure Hazards and Metal Analysis Resulting from Bauxite Samples Collected from a Saudi Arabian Mine
}

\author{
Saleh Alashrah ${ }^{1 *}$, Atef El-Taher ${ }^{2}$ \\ ${ }^{1}$ Physics Department, College of Science, Qassim University, Buridah 51452, Kingdom of Saudi Arabia \\ ${ }^{2}$ Physics Department, Faculty of Science, Al-Azhar University, Assuit 71452, Egypt
}

Received: 12 April 2017

Accepted: 31 June 2017

\begin{abstract}
Since bauxite is a rock consisting of aluminum oxide, it is significant to measure natural radionuclide concentrations for occupational health purposes. The bauxite mine is located in the city of Az Zabirah in the Qassim region in Saudi Arabia. The radionuclide concentrations of ${ }^{226} \mathrm{Ra},{ }^{232} \mathrm{Th}$, and ${ }^{40} \mathrm{~K}$ in bauxite samples were measured using a $\gamma$-ray spectrometer $\mathrm{NaI}(\mathrm{Tl})$. The average and range values of ${ }^{226} \mathrm{Ra},{ }^{232} \mathrm{Th}$, and ${ }^{40} \mathrm{~K}$ radioactivity concentrations were $83.7 \pm 0.3$ (164.2-35.2), $107.3 \pm 1.3$ (199.9-48.5), and 192.0 \pm 1.1 (487.1-24.6), Bq/kg respectively. These results were compared with published global limits of ${ }^{226} \mathrm{Ra},{ }^{232} \mathrm{Th}$, and ${ }^{40} \mathrm{~K}$ by (UNSCEAR, 2000; ICRP-60). The radiation hazard parameters were also calculated and compared with the recommended levels. There are no studies for the natural radioactivity in the bauxite mine in Az Zabirah, so these results are a start to establishing a database in this location. Furthermore, $\mathrm{x}$-ray fluorescence (XRF) was used to determine the concentrations of elements and their oxides for the bauxite samples.
\end{abstract}

Keywords: bauxite, natural radioactivity, radiation hazard parameters

\section{Introduction}

Natural occurring radionuclides are present in many natural resources. Human activities may enhance concentrations of radionuclides and/or enhance potential exposure to naturally occurring radioactive material (NORM). Industrial residues containing radionuclides have been receiving considerable global attention because of the large amounts of NORM-containing wastes and the potential long-term risks of long-lived radionuclides [1]. They have become concentrated and exposed not only to

*e-mail: salashra@gmail.com the environment but also to mine workers. Actually, there are a number of authors who have published papers about radiation hazard assessment resulting from phosphate, oil, or gas production [2]. Although aluminum has been widely used in industry, there are few studies focusing on radiation risk from bauxite or red mud [3]. Table 1 shows the range of radionuclides concentrations in bauxite. The activity concentrations of ${ }^{238} \mathrm{U}$ and ${ }^{232} \mathrm{Th}$ were high because ${ }^{238} \mathrm{U}$ and ${ }^{232} \mathrm{Th}$ decay series depends on geological composition.

O'Connor [4-5] measured natural activity concentrations in bauxite, solid residues, and red mud resulting from alumina production in western Australia. ${ }^{238} \mathrm{U}$ concentration results were $120-350$ 
Table 1. Content of radionuclides in bauxite and red mud [9].

\begin{tabular}{|c|c|c|}
\hline \multirow{2}{*}{ Radionuclide } & \multicolumn{2}{|c|}{ Specific activity $(\mathrm{Bq} / \mathrm{Kg})$} \\
\cline { 2 - 3 } & Bauxite & Red mud \\
\hline${ }^{238} \mathrm{U}^{226}$ Ra decay series & $10-900$ & $100-3,000$ \\
\hline${ }^{232} \mathrm{Th}$ decay series & $35-1,400$ & $100-300$ \\
\hline${ }^{40} \mathrm{~K}$ & $10-600$ & $10-100$ \\
\hline
\end{tabular}

(bauxite), 5-200 (soil residues), and 150-600 (red mud). Furthermore, the activity concentrations of ${ }^{232} \mathrm{Th}$ were (450-1,050), (300-800) and (1,000-1,900) for bauxite, soil residues, and red mud, respectively. Radionuclide concentrations of red mud increase three times compared to the original bauxite mineral due to refined bauxite and produce alumina. The highest concentrations of uranium or thorium radionuclides are transferred to solid waste. However, little, if none, of their radionuclides are found in alumina. To reduce occupational exposure, many studies have reported that a percentage of red mud can be mixed with concrete or cement [6]. The absorbed dose of the mixed red mud should not exceed the limit determined by UNSCEAR (2000) [7]. Therefore, manufacturing operation reduces the radiation hazard parameters. Furthermore, Righi et al. [8] measured the natural radioactivity in bauxite. Their results showed that the activity concentrations of ${ }^{238} \mathrm{U}$ were between 500 and $600 \mathrm{~Bq} / \mathrm{kg}$ and from 400 to $450 \mathrm{~Bq} / \mathrm{kg}$ for ${ }^{232} \mathrm{Th}$.

Ademola et al. [10] studied the activity concentration of ${ }^{226} \mathrm{Ra},{ }^{232} \mathrm{Th}$, and ${ }^{40} \mathrm{~K}$ in bauxite ore in Nigeria using a $\mathrm{NaI}(\mathrm{Tl})$ detector. They concluded that the mean values of ${ }^{226} \mathrm{Ra},{ }^{232} \mathrm{Th}$, and ${ }^{40} \mathrm{~K}$ changed from $47 \pm 14$ to $134 \pm 21$. When high pure germanium and neutron activation methods were used for bauxite measurement, the results were $37 \pm 12 \mathrm{~Bq} \cdot \mathrm{kg}^{-1}$ for ${ }^{238} \mathrm{U}, 154 \pm 16 \mathrm{~Bq} \cdot \mathrm{kg}^{-1}$ for ${ }^{232} \mathrm{Th}$, and $9.4 \pm 0.2$ for ${ }^{40} \mathrm{~K}$ [1]. The activity concentrations of bauxite samples in the Gulf of Corinth in Greece were determined using direct $\gamma$-ray spectroscopy [11]. The results showed that the activity concentrations of ${ }^{226} \mathrm{Ra},{ }^{232} \mathrm{Th}$, and ${ }^{40} \mathrm{~K}$ were 150,205 , and 38 , respectively. The average world activity concentrations of ${ }^{226} \mathrm{Ra},{ }^{232} \mathrm{Th}$, and ${ }^{40} \mathrm{~K}$ were 50 , 50 , and $500 \mathrm{~Bq} / \mathrm{Kg}$, respectively [7].

Regarding EDXRF, Yatkin et al. [12] compared the results of energy dispersive X-ray fluorescence (EDXRF) and inductively coupled plasma mass spectrometry (ICP-MS) for element concentrations in bauxite. These elements were lead $(\mathrm{Pb})$, arsenic (As), nickel (Ni), cadmium $(\mathrm{Cd})$, copper $(\mathrm{Cu})$, chromium $(\mathrm{Cr})$, and zinc $(\mathrm{Zn})$. Other elements such as aluminum (Al), calcium $(\mathrm{Ca})$, iron $(\mathrm{Fe})$, magnesium $(\mathrm{Mg})$, silicon $(\mathrm{Si})$, chloride $(\mathrm{Cl})$, potassium $(\mathrm{K})$, sulphur $(\mathrm{S})$, manganese $(\mathrm{Mn})$, molybdenum (Mo), cobalt (Co), strontium (Sr), bromide $(\mathrm{Br})$, titanium $(\mathrm{Ti})$, tin $(\mathrm{Sn})$, and antimony $(\mathrm{Sb})$ were also tested. They concluded that there was good agreement in element analysis between ICP-MS and EDXRF for most elements, and the uncertainty in element concentrations was low.
The objective of the present work is to determine Al content in the bauxite mine in Az Zabirah using ARL Quant'X (Thermo Scientific Inc, USA) EDXRF and compare our results with similar studies in other countries. Furthermore, this study aims to measure the natural radioactivity levels of ${ }^{226} \mathrm{Ra},{ }^{232} \mathrm{Th}$, and ${ }^{40} \mathrm{~K}$ in the samples using $\gamma$-ray spectrometry and calculate the radiation hazard parameters such as radium equivalent activity (Raeq), external hazard index (Hex), and absorbed dose rate.

\section{Experimental}

\section{Study Area}

Az Zabirah (N27056', E43043') is located in the northeastern Qassim region (Fig. 1) [13], and it has a bauxite mine. It has a laterite profile because it is rich in iron and aluminum. It is more than $105 \mathrm{~km}$ into the scarp face of an early Cretaceous feature. The estimated total reserves are 101.8 million tons. Of course, the laterite development could be older than Oligocene. The thickness of bauxite is approximately $8.5 \mathrm{~m}$ described [13]. Az Zabirah is in the cuesta region of central Saudi Arabia.

\section{Sampling and Sample Preparation}

Forty samples of the bauxite were collected from $\mathrm{Az}$ Ziberah in the Qassim region. The samples were ground and sieved using a standard set of sieves. Weighed samples were put in polyethylene bottles of $350 \mathrm{~cm}^{3}$ volume. The bottles were completely sealed for more than one month to allow radioactive equilibrium to be reached. This step was necessary to ensure that radon was removed from the volume [14-16]. Each powdered sample was homogenized using an electric shaker [17].

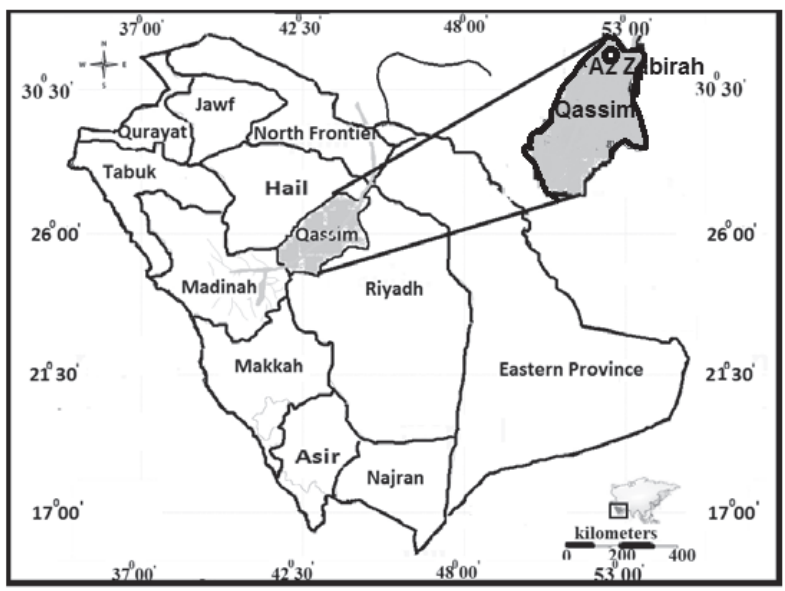

Fig. 1. Location of Az Zabirah in Saudi Arabia. 


\section{$\gamma$-ray Spectrometer $\mathrm{NaI}(\mathrm{Tl})$}

A $\mathrm{NaI}(\mathrm{Tl})$ detector was used to measure natural radionuclide activity. It was calibrated using a known source such as ${ }^{60} \mathrm{Co}$ and ${ }^{137} \mathrm{Cs}$ point sources. In order to calculate radionuclide activity, the concentration for each gamma-ray photo-peak relies on the secular equilibrium between parents and daughters in the samples:

$$
A=\frac{N_{P} \times 100}{e \times \eta \times m}
$$

...where $\mathrm{Np}$ is the net count rate (cps), e is the abundance of the $\gamma$-peak in a radionuclide, $m$ is the mass of sample, and $\eta$ is the measured efficiency for each gamma-ray peak observed for the same number of channels.

The count rate was subtracted from an empty polystyrene container using the same manner as measured samples to obtain the net count rate. The values of e and $\eta$ for each isotope used to calculate the activity concentrations of ${ }^{226} \mathrm{Ra},{ }^{232} \mathrm{Th}$, and ${ }^{40} \mathrm{~K}$ are shown in Table 2 . The measuring time for gamma-ray spectra was $43,200 \mathrm{~s}[15,18-22]$.

\section{X-ray Fluorescence (XRF)}

We used an ARL Quant'X (EDXRF) manufactured by Thermo Scientific Inc, USA for elemental analysis. It can analyze elements ranging from ${ }^{22} \mathrm{Na}$ to heavy elements such as ${ }^{238} \mathrm{U}$. A material can be excited when it collides with high-energy x-rays. The anode material of an x-ray tube consists of rhodium (whose symbol is Rh and atomic number 45), and the voltage changes between 4 and $50 \mathrm{kV}$. The detector is made from semiconductor $\mathrm{Si}(\mathrm{Li})$ material. It is a cylindrical shape with $15 \mathrm{~mm}^{2}$ cylindrical area and $3.5 \mathrm{~mm}$ cylindrical depth. Table 3 shows a list of filters used to decrease the x-ray energy to the correct excitation bandwidth of the elements to be analyzed [12].
Table 3. Operational parameters of EDXRF.

\begin{tabular}{|c|c|c|c|}
\hline Beam filter & Beam filter & Live time $(\mathrm{sec})$ & Element \\
\hline $\mathrm{Cu}$ thick & 50 & 240 & $\mathrm{Sn}, \mathrm{Sb}$ \\
\hline $\mathrm{Cu}$ thin & 50 & 800 & $\mathrm{Mo}, \mathrm{Cd}$ \\
\hline Pd thick & 30 & 1,600 & $\mathrm{As}, \mathrm{Br}, \mathrm{Sr}, \mathrm{Pb}$ \\
\hline Pd medium & 20 & 960 & $\mathrm{Cu}, \mathrm{Zn}$ \\
\hline Pd thin & 16 & 600 & $\mathrm{Fe}, \mathrm{Co}, \mathrm{Ni}, \mathrm{Mn}$ \\
\hline Aluminum & 12 & 1,000 & $\mathrm{Ti}, \mathrm{V}, \mathrm{Cr}$ \\
\hline Cellulose & 8 & 200 & $\mathrm{~S}, \mathrm{Cl}, \mathrm{K}, \mathrm{Ca}$ \\
\hline No filter & 4 & 100 & $\mathrm{Mg}, \mathrm{Al}, \mathrm{Si}$ \\
\hline
\end{tabular}

\section{Results and Discussion}

\section{Activity Concentrations of ${ }^{226} \mathrm{Ra},{ }^{232} \mathrm{Th}$, and ${ }^{40} \mathrm{~K}$}

The activity concentrations of ${ }^{226} \mathrm{Ra},{ }^{232} \mathrm{Th}$, and ${ }^{40} \mathrm{~K}$ in the bauxite samples in Az Zabirah are shown in Table 4. According to the recommended reference level [7], the activity concentration should be less than 50,50 , and $500 \mathrm{~Bq} / \mathrm{kg}$ for ${ }^{226} \mathrm{Ra},{ }^{232} \mathrm{Th}$, and ${ }^{40} \mathrm{~K}$, respectively. The average values of ${ }^{226} \mathrm{Ra}$ and ${ }^{232} \mathrm{Th}$ in the bauxite samples were higher than the recommended reference level (Table 4). However, the activity concentrations of ${ }^{40} \mathrm{~K}$ were lower than the recommended reference level [7]. Table 5 shows the comparison between the activity concentrations of ${ }^{226} \mathrm{Ra},{ }^{232} \mathrm{Th}$, and ${ }^{40} \mathrm{~K}$ in the bauxite samples in this study with those by other investigations in different locations around the world. The average value of ${ }^{226} \mathrm{Ra}$ in this study was higher than the average value of ${ }^{226} \mathrm{Ra}$ measured in India, Guinean, the Gulf of Itea in Greece, and Brazil. However, our result was lower than for Greece, Antikyra Bay, Hungary, China, and Turkey. Regarding the result of ${ }^{232} \mathrm{Th}$, our result was lower than all countries. However, ${ }^{40} \mathrm{~K}$ was the highest value. Figure 2 illustrates the correlations between ${ }^{226} \mathrm{Ra},{ }^{232} \mathrm{Th}$, and ${ }^{40} \mathrm{~K}$. We noted good correlation between ${ }^{226} \mathrm{Ra}$ and ${ }^{232} \mathrm{Th}$ and between ${ }^{226} \mathrm{Ra}$ and ${ }^{40} \mathrm{~K}$, with correlation coefficients of 0.99 and 0.95 , respectively.

Table 2. Gamma rays and their related isotopes used to calculate the activity concentrations of ${ }^{226} \mathrm{Ra}$, ${ }^{232} \mathrm{Th}$, and ${ }^{40} \mathrm{~K}$.

\begin{tabular}{|c|c|c|c|c|}
\hline \multirow{2}{*}{ Nuclide } & Isotopes & $\begin{array}{c}\text { Energy } \\
(\mathrm{KeV})\end{array}$ & $\begin{array}{c}\text { Measured efficiency for each } \\
\text { gamma-ray peak }(\eta)(\%)\end{array}$ & $\begin{array}{c}\text { Abundance of } \gamma \text {-peak in a } \\
\text { radionuclide }(e)\end{array}$ \\
\hline \multirow{5}{*}{${ }^{226} \mathrm{Ra}$} & ${ }^{214} \mathrm{~Pb}$ & 351.90 & 37 & 0.21 \\
\cline { 2 - 5 } & ${ }^{214} \mathrm{Bi}$ & 609.30 & 46 & 0.12 \\
\cline { 2 - 5 } & ${ }^{214} \mathrm{Bi}$ & $1,120.30$ & 15 & 0.08 \\
\cline { 2 - 5 } & ${ }^{214} \mathrm{Bi}$ & $1,764.5$ & 15.9 & 0.067 \\
\hline \multirow{2}{*}{${ }^{232} \mathrm{Th}$} & ${ }^{228} \mathrm{Ac}$ & 911.10 & 29 & 0.25 \\
\cline { 2 - 5 } & ${ }^{212} \mathrm{~Pb}$ & 238.60 & 44 & 0.07 \\
\hline
\end{tabular}


Table 4. Activity concentrations $\left({ }^{226} \mathrm{Ra},{ }^{232} \mathrm{Th}\right.$, and $\left.{ }^{40} \mathrm{~K}\right)$ in the bauxite samples in the study area.

\begin{tabular}{|c|c|c|c|}
\hline \multirow{2}{*}{ Sample number } & \multicolumn{3}{|c|}{ Activity concentrations } \\
\hline & ${ }^{226} \mathrm{Ra}$ & ${ }^{232} \mathrm{Th}$ & ${ }^{40} \mathrm{k}$ \\
\hline 1 & 37.2 & 54.1 & 30.0 \\
\hline 2 & 35.4 & 52.2 & 30.1 \\
\hline 3 & 35.4 & 50.7 & 24.6 \\
\hline 4 & 42.3 & 58.9 & 35.0 \\
\hline 5 & 49.5 & 70.1 & 46.8 \\
\hline 6 & 45.9 & 62.6 & 44.9 \\
\hline 7 & 53.7 & 73.5 & 51.1 \\
\hline 8 & 52.1 & 72.5 & 50.2 \\
\hline 9 & 45.1 & 64.6 & 59.0 \\
\hline 10 & 77.9 & 112.9 & 96.4 \\
\hline 11 & 61.4 & 84.6 & 52.6 \\
\hline 12 & 65.6 & 95.4 & 71.0 \\
\hline 13 & 61.3 & 86.2 & 77.8 \\
\hline 14 & 60.7 & 84.5 & 67.3 \\
\hline 15 & 51.2 & 71.0 & 62.8 \\
\hline 16 & 58.4 & 80.7 & 84.5 \\
\hline 17 & 56.8 & 77.5 & 84.3 \\
\hline 18 & 152.2 & 178.2 & 444.5 \\
\hline 19 & 139.4 & 166.1 & 419.5 \\
\hline 20 & 159.4 & 199.9 & 443.7 \\
\hline 21 & 148.4 & 178.1 & 423.2 \\
\hline 23 & 164.2 & 197.2 & 487.1 \\
\hline 24 & 161.2 & 198.1 & 460.6 \\
\hline 25 & 103.3 & 127.6 & 298.2 \\
\hline 26 & 101.9 & 124.5 & 288.9 \\
\hline 27 & 40.6 & 54.9 & 74.1 \\
\hline 28 & 51.9 & 67.2 & 92.6 \\
\hline 29 & 35.3 & 48.5 & 61.8 \\
\hline 30 & 54.5 & 75.6 & 96.2 \\
\hline 31 & 54.8 & 74.0 & 101.8 \\
\hline 32 & 161.5 & 198.4 & 461.3 \\
\hline 33 & 104.1 & 128.4 & 168.4 \\
\hline 34 & 100.7 & 123.9 & 292.6 \\
\hline 35 & 99.1 & 120.9 & 283.6 \\
\hline 36 & 81.2 & 97.6 & 233.6 \\
\hline 37 & 86.4 & 105.1 & 245.1 \\
\hline 38 & 88.1 & 106.9 & 286.1 \\
\hline 39 & 139.0 & 169.3 & 409.9 \\
\hline 40 & 148.0 & 191.3 & 446.0 \\
\hline Average & 83.7 & 107.3 & 192.0 \\
\hline
\end{tabular}

Radiation hazard parameters can be estimated using indices such as radium equivalent, absorbed dose, and the annual effective dose. The distribution of ${ }^{226} \mathrm{Ra},{ }^{232} \mathrm{Th}$, and ${ }^{40} \mathrm{~K}$ in samples are not uniform. To obtain the same gamma dose rate, the activity concentration from the three radionuclides are assumed to be $370 \mathrm{~Bq} \cdot \mathrm{kg}^{-1}$ from ${ }^{226} \mathrm{R}, 259 \mathrm{~Bq} \cdot \mathrm{kg}^{-1}$ from ${ }^{232} \mathrm{Th}$, and $4810 \mathrm{~Bq} \cdot \mathrm{kg}^{-1}$ from ${ }^{40} \mathrm{~K}$. This is the definition of radium equivalent and is given as Equation 2:

$$
\mathrm{Ra}_{\mathrm{eq}}=\mathrm{A}_{\mathrm{Ra}}+1.43 \times \mathrm{A}_{\mathrm{Th}}+0.077 \times \mathrm{A}_{\mathrm{k}}
$$

...where $A_{R a}, A_{T h}$, and $A_{K}$ are the activity concentrations of ${ }^{226} \mathrm{Ra},{ }^{232} \mathrm{Th}$, and ${ }^{40} \mathrm{~K}$ in $\mathrm{Bq} \cdot \mathrm{kg}^{-1}$, respectively. Regarding radiological hazard, the maximum Raeq in the bauxite samples must be less than $370 \mathrm{~Bq} \mathrm{~kg}^{-1}$ for safe use. The calculated Raeq results obtained from bauxite samples are presented in Fig. 3a). The radium equivalent results ranged from $109.4 \pm 10$ to $483.8 \pm 34 \mathrm{~Bq} \cdot \mathrm{kg}^{-1}$, and mean value was 251.9. The average value was in the safety recommended limit. These results were comparable with the results obtained from bauxite in Nigeria (189-262 $\mathrm{Bq} \cdot \mathrm{kg}^{-1}$ with mean value $\left.222 \mathrm{~Bq} \cdot \mathrm{kg}^{-1}\right)$ [17]. Furthermore, the absorbed dose rate in air at $1 \mathrm{~m}$ above the ground surface was calculated at different sampling points using Equation 3:

$$
\mathrm{D}_{\mathrm{R}}\left(\mathrm{nG} \mathrm{h}^{-1}\right)=0.427 \mathrm{~A}_{\mathrm{Ra}}+0.623 \mathrm{~A}_{\mathrm{Th}}+0.043 \mathrm{~A}_{\mathrm{K}}
$$

The values varied from 48.0 to $215.3 \mathrm{nGy} / \mathrm{h}$ and the average value was $111.5 \mathrm{nGy} / \mathrm{h}$ in the Az Zabirah bauxite mine as shown in Fig. 3a). The average obtained value calculated based on Equation (3) was higher than the worldwide average value of $60.0 \mathrm{nGy} / \mathrm{h}$ [7]. The average effective dose value at which populations are exposed to gamma rays in the Az Zabirah mine was $0.14 \mathrm{mSv} /$ year. The obtained average value was lower than the recommended level $(1.0 \mathrm{mSv} / \mathrm{year})$ [7]. The calculation value of the absorbed dose rate in air at $1 \mathrm{~m}$ above ground level and the annual effective dose to which a population may likely be exposed at different sampling

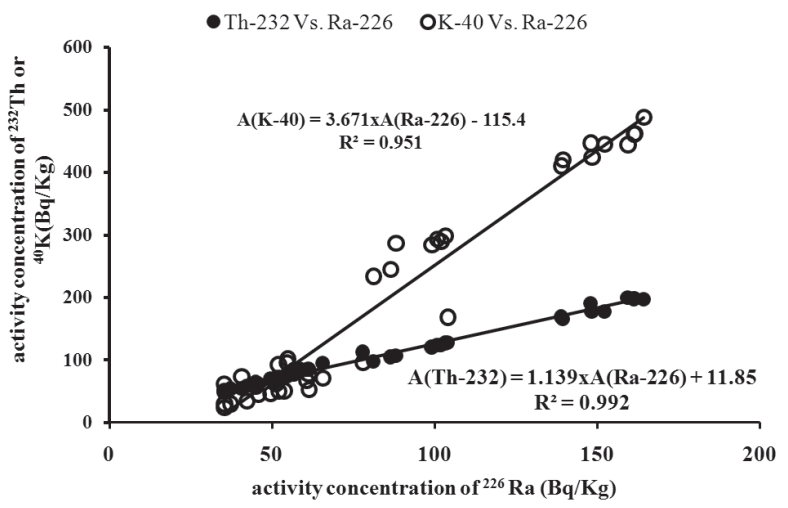

Fig. 2. Correlations between ${ }^{226} \mathrm{Ra}$ and ${ }^{232} \mathrm{Th}(\bullet)$ and ${ }^{226} \mathrm{Ra}$ and ${ }^{40} \mathrm{~K}(\circ)$ in the bauxite samples in Qassim Province, Saudi Arabia. 
Table 5. Comparison of natural radioactivity concentrations of ${ }^{226} \mathrm{Ra},{ }^{232} \mathrm{Th}$, and ${ }^{40} \mathrm{~K}$ in the bauxite samples between the present study and published papers in other countries around the world.

\begin{tabular}{|c|c|c|c|c|c|}
\hline \multirow{2}{*}{ Country } & \multirow{2}{*}{ Description } & \multicolumn{3}{|c|}{ Activity concentration $\left(\mathrm{Bqkg}^{-1}\right)$} & \multirow{2}{*}{ References } \\
\hline & & ${ }^{226} \mathrm{Ra}$ & ${ }^{232} \mathrm{Th}$ & ${ }^{40} \mathrm{~K}$ & \\
\hline Saudi Arabia, Az Zabirah & bauxite & 83.7 & 107.3 & 192.0 & Present study \\
\hline Guinea & Bauxite & 51.2 & 227 & ----- & [23] \\
\hline India & Bauxite & 70.2 & 499 & ---- & {$[23]$} \\
\hline Brazil & Bauxite & 64 & 154 & 9.4 & [1] \\
\hline Greece, Gulf of Itea & Bauxite & 72.8 & 185 & 43 & {$[24]$} \\
\hline Greece, Antikyra Bay & Bauxite & 150 & 205 & 28.3 & [11] \\
\hline Hungary & Bauxite & 419.0 & 256.0 & 47.0 & {$[25]$} \\
\hline China & Bauxite & 370.0 & 400.0 & 63.0 & {$[8]$} \\
\hline Turkey & Bauxite & $15.5-405$ & $19.9-414$ & $12.8-111.6$ & {$[26]$} \\
\hline
\end{tabular}

points in these study sites are shown in Fig. 4. The hazard index parameters calculated to assess the level of risk to which the population may be exposed to the terrestrial radiation from bauxite are shown in Fig. 3b). The obtained average values of the external hazard index (Hex) and the internal hazard index (Hin) were 0.7
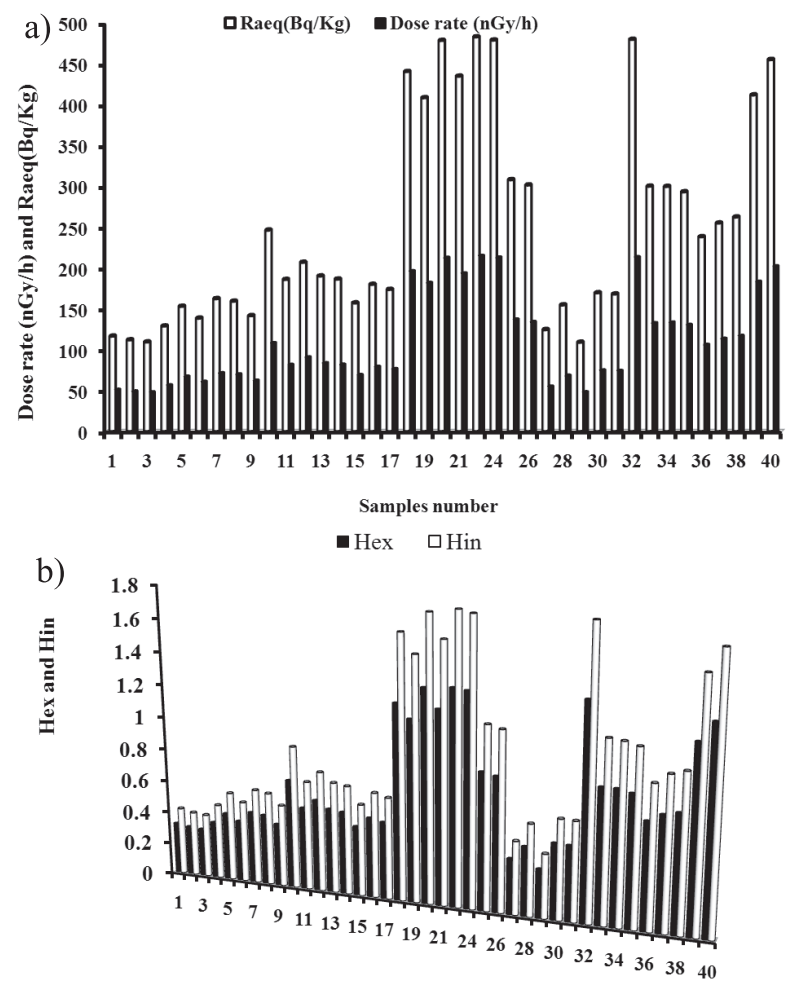

Samples numbe

Fig. 3. a) Air-absorbed dose rates and radium equivalent calculated for bauxite samples collected from Az Zabirah in Qassim Province and b) calculated hazard index parameters, external index (Hex), and internal index (Hin) collected from the mine. and 0.9 , respectively. The obtained average values of both hazard indices were lower than the recommended level [7].

\section{Chemical Analysis by EDXRF}

Energy dispersive $\mathrm{X}$-ray fluorescence analysis (ARL Quant'X EDXRF) was used to determine major and minor element concentrations and their oxides in the bauxite samples as shown in Table 6. Aluminum oxide $\left(\mathrm{Al}_{2} \mathrm{O}_{3}\right)$ was the highest value, ranging between $63.3 \%$ and $40 \%$, and the average percentage value was $56.7 \%$. This result agrees with other studies [27-28]. Impurities, humidity, and location from which the bauxite was mined have a significant effect on the element's composition [3].

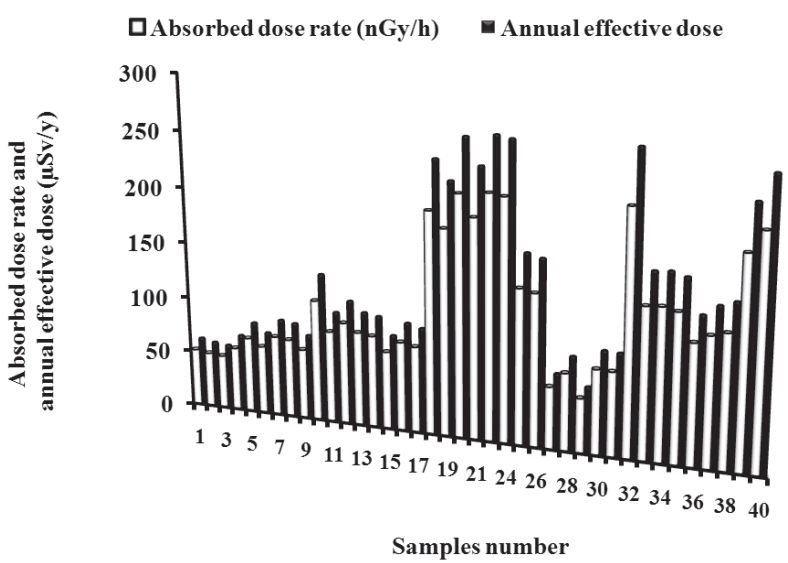

Fig. 4. Air-absorbed dose rates and annual effective doses calculated for the bauxite mine samples collected from $\mathrm{Az}$ Zabirah in Qassim Province. 
Table 6. Chemical composition of bauxite samples collected from Az Zabirah mine in Qassim Province, Saudi Arabia.

\begin{tabular}{|c|c|c|c|c|c|c|c|c|c|c|c|c|c|}
\hline \multirow{2}{*}{$\begin{array}{l}\text { Sample } \\
\text { number }\end{array}$} & \multicolumn{13}{|c|}{ Element oxide (\%) } \\
\hline & $\mathrm{Al}_{2} \mathrm{O}_{3}$ & $\mathrm{SiO}_{2}$ & $\mathrm{TiO}_{2}$ & $\mathrm{Fe}_{2} \mathrm{O}_{3}$ & $\mathrm{Na}_{2} \mathrm{O}$ & $\mathrm{MgO}$ & $\mathrm{SO}_{3}$ & $\mathrm{CaO}$ & $\mathrm{ZrO}_{2}$ & $\mathrm{SrO}$ & $\mathrm{Cr}_{2} \mathrm{O}_{3}$ & $\mathrm{MnO}$ & $\mathrm{Nb}_{2} \mathrm{O}_{5}$ \\
\hline 1 & 40,1 & 39.8 & 4.5 & 2.6 & ---- & 7.7 & 3.0 & 1.6 & 0.4 & 0.02 & 0.02 & 0.01 & 0.03 \\
\hline 2 & 40.8 & 38.1 & 4.7 & 3.0 & ---- & 8.2 & 3.1 & 1.7 & 0.4 & 0.03 & 0.02 & 0.02 & 0.03 \\
\hline 3 & 58.7 & 26.1 & 5.2 & 6.1 & --- & --- & 2.3 & 0.7 & 0.5 & 0.3 & 0.06 & 0.04 & 0.04 \\
\hline 4 & 63.0 & 25.0 & 4.3 & 4.8 & --- & 1.9 & 1.0 & 0.5 & 0.4 & 0.1 & --- & 0.03 & 0.03 \\
\hline 5 & 42.1 & 31.0 & 2.9 & 2.1 & 11.2 & 7.7 & 1.6 & 1.0 & 0.3 & 0.05 & ----- & 0.01 & 0.02 \\
\hline 6 & 27.4 & 25.9 & 3.0 & 1.8 & 32.6 & 5.4 & 2.3 & 1.3 & 0.3 & 0.02 & ----- & --- & 0.01 \\
\hline 7 & 57.0 & 24.8 & 5.0 & 7.1 & --- & 2.0 & 2.5 & 0.6 & 0.6 & 0.3 & ---- & --- & 0.05 \\
\hline 8 & 63.3 & 22.2 & 6.7 & 4.1 & ----- & ----- & ---- & 2.5 & 0.9 & 0.07 & 0.05 & 0.03 & 0.04 \\
\hline 9 & 62.3 & 25.8 & 4.6 & 4.5 & ---- & 1.7 & ---- & 0.4 & 0.5 & 0.1 & ---- & 0.02 & 0.03 \\
\hline 10 & 58.6 & 20.3 & 5.9 & 3.2 & 7.0 & 1.8 & ---- & 1.9 & 0.8 & 0.05 & ----- & 0.02 & 0.03 \\
\hline 11 & 55.5 & 26.0 & 4.1 & 3.7 & 4.8 & 1.7 & 2.1 & 1.4 & 0.4 & 0.1 & 0.04 & 0.02 & 0.03 \\
\hline 12 & 59.0 & 22.3 & 3.6 & 3.7 & 7.8 & 1.6 & 1.0 & 0.4 & 0.3 & 0.08 & 0.04 & 0.02 & 0.02 \\
\hline 13 & 57.5 & 27.5 & 4.6 & 4.0 & ---- & 2.0 & ---- & 1.5 & 0.5 & 0.15 & 0.04 & 0.03 & 0.03 \\
\hline 14 & 56.2 & 23.9 & 4.2 & 4.6 & 6.6 & 1.7 & 1.4 & 0.6 & 0.4 & 0.2 & 0.05 & 0.02 & 0.03 \\
\hline 16 & 61.6 & 25.1 & 4.9 & 5.5 & ---- & ---- & 1.7 & 0.5 & 0.4 & 0.2 & 0.05 & 0.03 & 0.04 \\
\hline 17 & 56.6 & 25.2 & 3.9 & 3.0 & 6.1 & 1.8 & 1.3 & 1.4 & 0.5 & 0.1 & 0.04 & 0.03 & ----- \\
\hline 18 & 61.9 & 24.7 & 4.4 & 5.1 & ---- & 1.7 & 1.1 & 0.5 & 0.4 & 0.2 & ----- & 0.03 & 0.03 \\
\hline 19 & 58.0 & 31.0 & 4.3 & 2.9 & ---- & 1.7 & 1.2 & 0.4 & 0.4 & 0.1 & 0.03 & ---- & 0.03 \\
\hline 20 & 60.0 & 28.8 & 3.7 & 4.7 & ---- & 1.9 & --- & 0.3 & 0.3 & 0.06 & ---- & 0.03 & 0.02 \\
\hline 21 & 61.8 & 23.6 & 4.9 & 3.6 & ---- & 1.9 & 1.5 & 1.7 & 0.6 & 0.3 & ----- & ---- & 0.03 \\
\hline 22 & 58.8 & 21.5 & 3.8 & 4.2 & 7.7 & 1.7 & 1.4 & 0.4 & 0.3 & 0.08 & ----- & 0.02 & 0.02 \\
\hline 23 & 60.7 & 26.5 & 4.7 & 5.3 & ---- & ---- & 1.6 & 0.6 & 0.4 & 0.2 & 0.04 & 0.03 & 0.03 \\
\hline 24 & 60.5 & 28.7 & 4.8 & 3.9 & ---- & ---- & ---- & 1.4 & 0.6 & ---- & ---- & 0.03 & 0.04 \\
\hline 25 & 40.8 & 35.6 & 3.8 & 2.2 & 5.1 & 8.2 & 2.5 & 1.4 & 0.3 & 0.0 & 0.0 & ---- & 0.0 \\
\hline 26 & 58.5 & 26.3 & 4.7 & 6.3 & ---- & ---- & 2.8 & 0.6 & 0.4 & 0.2 & ---- & 0.0 & ---- \\
\hline 27 & 42.1 & 34.1 & 4.0 & 2.4 & 4.6 & 8.3 & 2.4 & 1.7 & 0.3 & 0.0 & ---- & 0.0 & 0.0 \\
\hline 28 & 59.0 & 27.1 & 4.9 & 5.4 & ---- & ---- & 2.2 & 0.6 & 0.5 & 0.2 & 0.0 & ---- & 0.0 \\
\hline 29 & 60.4 & 20.1 & 5.3 & 3.2 & 6.1 & 2.1 & ---- & 1.9 & 0.7 & ---- & 0.0 & 0.0 & 0.0 \\
\hline 30 & 60.4 & 23.6 & 3.7 & 3.6 & 6.3 & 1.5 & ---- & 0.3 & 0.3 & 0.1 & 0.0 & ---- & 0.0 \\
\hline 31 & 59.8 & 22.2 & 3.8 & 3.4 & 8.0 & 1.8 & ---- & 0.5 & 0.3 & 0.1 & ---- & 0.0 & 0.0 \\
\hline 32 & 42.7 & 32.9 & 3.6 & 3.2 & 14.3 & ---- & 1.9 & 0.9 & 0.3 & 0.1 & ---- & ---- & 0.0 \\
\hline 33 & 61.9 & 24.4 & 6.8 & 3.6 & ---- & ---- & ---- & 2.3 & 0.9 & 0.1 & ---- & 0.0 & 0.0 \\
\hline 34 & 57.7 & 28.3 & 4.2 & 3.7 & ---- & 1.9 & 2.1 & 1.4 & 0.4 & 0.1 & ---- & 0.0 & 0.0 \\
\hline 35 & 61.6 & 27.6 & 3.9 & 2.6 & ---- & 2.0 & ---- & 1.4 & 0.4 & 0.1 & ---- & 0.0 & 0.0 \\
\hline 36 & 55.9 & 24.2 & 3.6 & 2.9 & 8.0 & 1.8 & 1.8 & 1.3 & 0.3 & 0.1 & ---- & 0.0 & 0.0 \\
\hline 37 & 56.8 & 29.3 & 4.2 & 4.6 & ---- & 1.9 & 1.8 & 0.7 & 0.4 & 0.2 & 0.0 & 0.0 & 0.0 \\
\hline 38 & 58.1 & 29.4 & 4.4 & 4.9 & ---- & ---- & 1.9 & 0.7 & 0.4 & 0.2 & 0.1 & 0.0 & 0.0 \\
\hline 39 & 60.5 & 28.4 & 3.7 & 4.4 & ---- & 2.0 & ---- & 0.6 & 0.3 & 0.1 & ---- & 0.0 & 0.0 \\
\hline
\end{tabular}


Table 6. Continued.

\begin{tabular}{|c|c|c|c|c|c|c|c|c|c|c|c|c|c|}
\hline 40 & 58.7 & 21.5 & 3.7 & 4.2 & 8.0 & 1.5 & 1.4 & 0.4 & 0.3 & 0.1 & 0.0 & 0.0 & 0.0 \\
\hline Mean & 56.7 & 26.9 & 4.4 & 4.0 & 3.6 & 2.4 & 1.5 & 1.0 & 0.4 & 0.1 & 0.0 & 0.0 & 0.0 \\
\hline Max & 63.3 & 39.8 & 6.8 & 7.1 & 14.3 & 8.3 & 3.1 & 2.5 & 0.9 & 0.3 & 0.1 & 0.0 & 0.1 \\
\hline Min & 40.1 & 20.1 & 2.9 & 2.1 & 4.6 & 1.5 & 1.0 & 0.3 & 0.3 & 0.0 & 0.0 & 0.0 & 0.0 \\
\hline
\end{tabular}

\section{Conclusion}

In order to estimate the radiation hazards resulting from a bauxite mine, it is important to determine radionuclide concentrations $\left({ }^{226} \mathrm{Ra},{ }^{232} \mathrm{Th},{ }^{40} \mathrm{~K}\right)$. The method of gamma spectrometry has been used to measure the radioactivity concentration of 40 samples collected from Az Zabirah bauxite mine in Qassim Province, Saudi Arabia. From this study, the range and average values of the concentrations of ${ }^{226} \mathrm{Ra},{ }^{232} \mathrm{Th}$, and ${ }^{40} \mathrm{~K}$ were $83.7 \pm 0.3$ (164.2-35.2), 107.3 \pm 1.3 (199.9-48.5), and 192.0 \pm 1.1 (487.124.6) $\mathrm{Bq} / \mathrm{kg}$, respectively. Overall, the study showed that the measured values for ${ }^{226} \mathrm{Ra}$ and ${ }^{232} \mathrm{Th}$ were higher than the recommended levels. The mean value of radium equivalent and total absorbed dose rate were $251.9 \mathrm{~Bq} / \mathrm{kg}$ and $111.5 \mathrm{nGy} . \mathrm{h}^{-1}$, respectively. The world average value of radium equivalent and absorbed dose are $370 \mathrm{~Bq} \cdot \mathrm{kg}^{-1}$ and $65 \mathrm{nGyh}^{-1}$. Annual effective gamma dose was lower than the world average. The internal and external hazard parameters in Az Zabirah were lower than the safe limit values used by UNSCEAR. The study area is a zone of high radiation levels, and it is possible to produce radiation hazards to the environment as well as the human health. However, this data may provide a general background level for the area studied and may serve as a guideline for future measurement and assessment of possible radiological risks to human health in this province.

\section{Acknowledgements}

The authors thank the Dean of Scientific Research at Qassim University for financial support under contract No. cos-2016-1-12-S-1409.

\section{References}

1. CUCCIA V., DE OLIVEIRA A.H., ROCHA Z. Radionuclideds in Bayer process residues: previous analysis for radiological protection. In: International nuclear atlantic conference INAC, IAEA, 24, 2011.

2. ABBADY A.G., UOSIF M., EL-TAHER A. Natural radioactivity and dose assessment for phosphate rocks from Wadi El-Mashash and El-Mahamid Mines, Egypt. Journal of Environmental radioactivity, 84, 65, 2005.

3. AKINCI. J. AKIN., Artir. Recep. Characterization of trace elements and radionuclides and their risk assessment in red mud. materials characterization. 59, 417, 2008.
4. COOPER M.B. Naturally occurring radioactive materials (NORM) in Australian industries review of current inventories and future generation. Report ERS-006 (EnviroRad Services Pty. Ltd.) to the Radiation health and Safety Advisory Council 2005.

5. O'CONNOR B.H., DONOGHUE A.M., MANNING T.J., CHESSON B.J. Radiological assessment for bauxite mining and alumina refining Annals of occupational hygiene mes, 52, 2012.

6. YANG QU., BIN LIAN Bioleaching of rare earth and radioactive elements from red mud using Penicilliumtricolor RM-10. Bioresource Technology, 136, 16, 2013.

7. UNSCEAR S. Effects of Ionizing Radiation United Nations, New York, 1, 453, 2000.

8. RIGHI S., VERITẢ S., ALBERTAZZI A., ROSSI P.L., BRUZZI L. Natural radioactivity in refractory manufacturing plants and exposure of workers to ionising radiation. Journal of Environmental radioactivity, 100, 540, 2009.

9. IAEA Extent of environmental contamination by naturally occurring radioactive material (NORM) and technological options for mitigation: Internat. Atomic Energy Agency), 419, 2003.

10. ADEMOLA J., AYOBAMI A., MICHAEL ADEKUNLE O. Evaluation of NORM and dose assessment in an aluminium industry in Nigeria World. Journal of Nuclear Science and Technology, 3, 150, 2013.

11. PAPATHEODOROU G., PAPAEFTHYMIOU H., MARATOU A., FERENTINOS G. Natural radionuclides in bauxitic tailings (red-mud) in the Gulf of Corinth, Greece. Radioprotection, 40, 549, 2005.

12. YATKIN S., GERBOLES M., BOROWIAK A. Evaluation of standardless EDXRF analysis for the determination of elements on PM10 loaded filters Atmospheric Environment, 54 568, 2012.

13. VINCENT P. Saudi Arabia: an environmental overview: CRC Press), 2008.

14. EL-TAHER A., ALASHRAH S. Occurrence of ${ }^{222} \mathrm{Rn}$ in irrigation water from Wadi Al-Rummah Qassim province, Saudi Arabia. In: PHYSICS AND MATERIALS SYMPOSIUM: International Conference on Applied Sciences and Industrial Technology (ICASIT2015): AIP Publishing) 020007, 2015.

15. ALASHRAH S., EL-TAHER A. Gamma Spectroscopic Analysis and Associated Radiation Hazards Parameters of Cement Used in Saudi Arabia. Journal of Environmental Science and Technology, 9, 238, 2016.

16. ALASHRAH S. Radiation properties for red soil in Qassim province, Saudi Arabia. Journal of Radiation Research and Applied Sciences, 9, 363, 2016.

17. EL-TAHER A., ALHARBI A. Elemental analysis of natural quartz from Um Higlig, Red Sea Aea, Egypt by instrumental neutron activation analysis. Applied Radiation and Isotopes, 82, 67, 2013. 
18. EL-TAHER A., AL-ZAHRANI J.H. Radioactivity measurements and radiation dose assessments in soil of Al-Qassim region, Saudi Arabia. Indian Journal of Pure \& Applied Physics (IJPAP), 52, 147, 2015.

19. EL-TAHER A., ABDELHALIM M.A.K. Elemental analysis of limestone by instrumental neutron activation analysis. Journal of radioanalytical and nuclear chemistry, 299, 1949, 2014.

20. EL-TAHER A., ABDELHALIM M.A.K. Elemental analysis of soils from Toshki by using instrumental neutron activation analysis techniques. Journal of radioanalytical and nuclear chemistry, 300, 431, 2014

21. EL-TAHER A., MADKOUR H. Environmental studies and radio-ecological impacts of Anthropogenic areas: shallow marine sediments Red Sea, Egypt J Isot. Environ Health Stud, 50, 120, 2014.

22. ALHARBI A., EL-TAHER A. Measurement of Natural Radioactivity and Radiation Hazard Indices for Dust Storm Samples from Qassim Region, Saudi Arabia. Life Science Journal, 11, 236, 2014

23. ABBADY A.G., EL-ARABI A. Naturally occurring radioactive material from the aluminium industry? a case study: the Egyptian Aluminium Company, Nag Hammady, Egypt. Journal of Radiological Protection, 26 415, 2006.

24. KARAGIANNIDI T., PAPAEFTHYMIOU H., PAPATHEODOROU G. Radioactive impact of a bauxite beneficiation plant in the Itea Gulf (Gulf of Corinth, Greece). Journal of radioanalytical and nuclear chemistry, 279, 923, 2009.

25. SOMLAI J., JOBBAGY V., KOVACS J., TARJAN S., KOVACS T. Radiological aspects of the usability of red mud as building material additive. Journal of hazardous materials, 150, 541, 2008

26. TURHAN S., ARIKAN I., DEMIREL H., GÜNGÖR N. Radiometric analysis of raw materials and end products in the Turkish ceramics industry. Radiation Physics and Chemistry, 80, 620, 2011.

27. MERGEN A. Production of sintered high alumina refractories from Turkish bauxite ore. British Ceramic Transactions, 103, 42, 2004.

28. CHUN. HUNG. YEH., GUANGQING. ZHANG. Stepwise carbothermal reduction of bauxite ores. International Journal of Mineral Processing, 124, 1, 2013. 